\section{DECAY OF ESCHERICHIA COLI IN SOIL FOLLOWING THE APPLICATION OF BIOSOLIDS TO AGRICULTURAL LAND}

\author{
N. L. Lang, BSc*, S. R. Smith, BSc, PhD (Member)* D. M. Bellett- \\ Travers, BSc, PhD*, E. B. Pike, BSc, PhD, CBiol, MIBiol (Fellow)** \\ and C. L. Rowlands, MSc. PhD. CBiol, MlBiol (Member) ${ }^{* * *}$
}

\section{ABSTRACT}

The decay of Escherichia coli in a sandy loam soil, amended with enhanced and conventionally treated biosolids, was investigated in a field experiment following spring and autumn applications of sewage sludge. Control soils, without the application of biosolids, were also examined to determine the background indigenous populations of $E$. coli which are present in the environment. The sunvival of indigenous $E$. coli and populations of $E$. coli applied to soil in biosolids, is assessed in relation to environmental factors influencing pathogen-decay processes in soil.

Key words: Biosolids; conventional treatment; decay; E. coli; enhanced treatment; pathogens; soil.

* Postgraduate Research Student, Director and Postdoctoral Research Assistant, respectively, Centre for Environmental Control and Waste Management, Department of Civil and Environmental Engineering, Imperial College, London, UK.

** Water and Public Health Microbiology Consultant, Sonning Common, Reading, UK.

*** Severn Trent Water Ltd, Birmingham, UK.

\section{INTRODUCTION}

The natural decay of enteric micro-organisms in soil following the application of sewage sludge, or any other type of faecal manure including livestock wastes, provides a final environmental barrier to the potential transmission of infectious disease. Understanding the survival characteristics of pathogenic micro-organisms in soil is therefore important for managing the potential microbiological risk to human and animal health associated with the use of biosolids as soil amendments in agriculture.

In general, enteric organisms are poorly adapted to survival in the environment, and pathogens which are introduced to soil (in sewage sludge) are influenced by climatic and agronomic variables. Soil and environmental factors (including moisture, temperature, sunlight, competitive organisms, nutrients and type of soil) and the method and timing of sludge application, influence the decay of faecal micro-organisms in biosolids treated soil. Crops which are ready to eat from the field are not produced in the UK on recently amended soil, and specified minimum harvesting periods apply to these and other types of crop to allow the natural decay of enteric organisms to control the potential risk of infection $^{[1.2]}$

The harvesting restrictions for agricultural land receiving biosolids are matched to the degree of pathogen removal which is achieved by different sludge-treatment processes. Conventionally treated sludge is regarded as having undergone stabilisation by a range of defined treatment methods (e.g. mesophilic anaerobic digestion), to ensure at least a $2 \log _{10}$ removal of $E$. coli, and should contain less than $10^{5} E$. coli per $g$ of dry solids (DS) ${ }^{137}$. (Note: $\log _{10}$ is used throughout the paper.) The absence of epidemiological evidence linking disease outbreaks in the human population ${ }^{(4)}$, or in farm livestock ${ }^{(5)}$ from the agricultural use of sewage sludge, strongly supports the role and effectiveness of these dual barriers in preventing the potential spread of infectious diseases from re-use on farmland.

Enhanced treatment is regarded as virtually eliminating the patho- genic content of sludge, and less-stringent management restrictions are applied when this category of biosolids is spread on farmland, compared with conventionally treated material. However, it could be argued that cropping, planting or havesting restrictions are unnecessary for this type of biosolids product, because the sludge-treatment process provides a critical control point for managing the microbiological risk from land application. Nevertheless, a minimum 10 -month harvesting restriction is a precautionary requirement of the 'safe sludge matrix' for enhanced treated biosolids which are used in fruit, salad and vegetable cultivation and other horticultural applications, consistent with the waiting period which is stipulated in the Directive ${ }^{(6)}$.

The time intervals which are required before certain crops can be grown after sludge application have been established on a precautionary basis. However, there are relatively few published data describing pathogen decay in sewage-sludge treated soil under temperate UK conditions. In this paper, initial results are presented from an ongoing programme of research to examine the fate of $E$. coli (a faecal indicator organism for the survival of enteric pathogens in the environment) in arable soil amended with conventionally and enhanced-treated biosolids during the spring and autumn periods.

\section{MATERIALS AND METHODS}

\section{Field trials}

The field experiments were located at the Imperial College field station, Silwood Park, Ascot. The soil was a free-draining moderately acidic sandy loam (70\% sand, $21 \%$ silt and $9 \%$ clay, pH 5.9 ), overlying a sand subsoil horizon. The trial area was cultivated with a tractor-mounted fixedtine harrow. Biosolids were applied to small plots $(1.5 \mathrm{~m} \times 1.5 \mathrm{~m})$ by hand at a rate equivalent to $10 \mathrm{t} / \mathrm{ha}$ DS and were incorporated immediately into the soil to a depth of $100 \mathrm{~mm}$ using a pedestrian-operated rotary cultivator. The biosolids included (a) dewatered anaerobically digested sludge (DMAD), (b) composted sludge with green waste (CPT), 
and (c) a thermally dried digested product (TDD). Biosolids products were applied on 5 June 2001 to Trial 1, which was completed after 84 days, and Trial 2 was amended with biosolids on 23 October 2001 and completed after a monitoring period of 119 days. Unamended control soil was also monitored to assess the background status of enteric micro-organisms in the trial plots.

Both field experiments were arranged as three randomised blocks in a split plot configuration. A group of sub-plots within each block was covered with perforated polythene film ( $2 \mathrm{~m}$ wide, 200 holes $\left./ \mathrm{m}^{2}\right)$ to manipulate soil environmental conditions, and the other split plot was maintained in a bare ground condition. Meteorological data were recorded by an automatic weather station, and soil temperature and moisture were monitored at depths of $0-50 \mathrm{~mm}$ and $50-100 \mathrm{~mm}$. The mean air and soil temperatures and soil-moisture content were calculated for a period of seven days (Fig. 1). Rainfall is also presented in Fig. 1 as a weekly cumulative value. (a) Trial 1
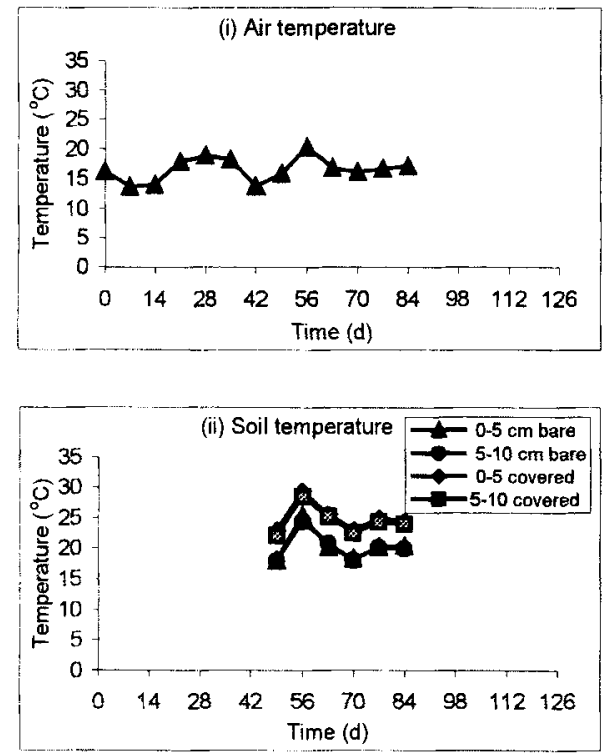

(iii) Rainfall
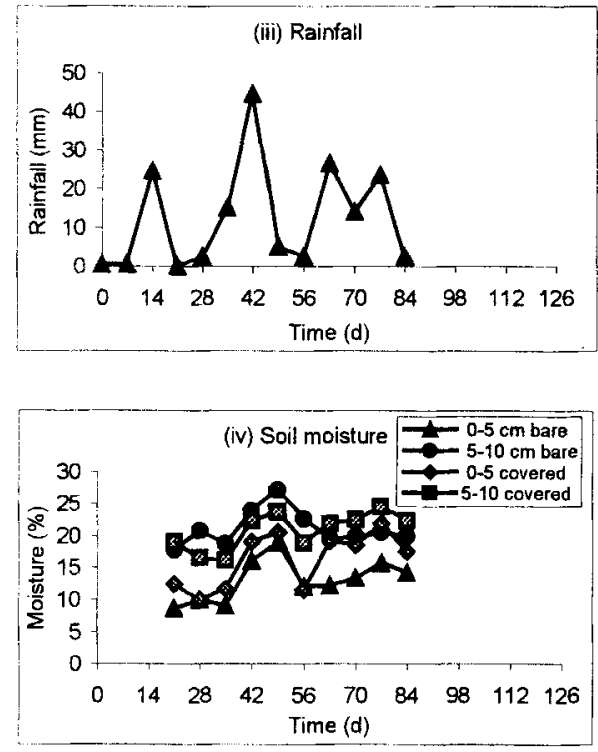

(b) Trial 2
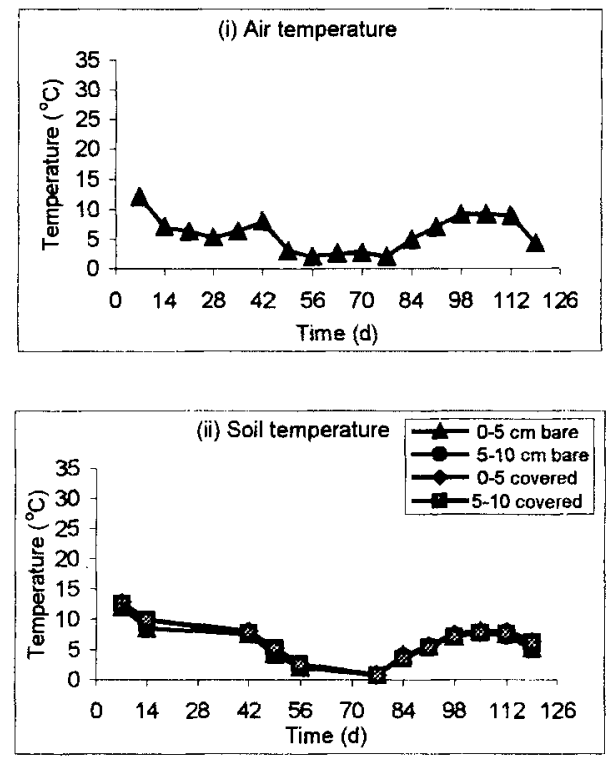

(iii) Rainfall
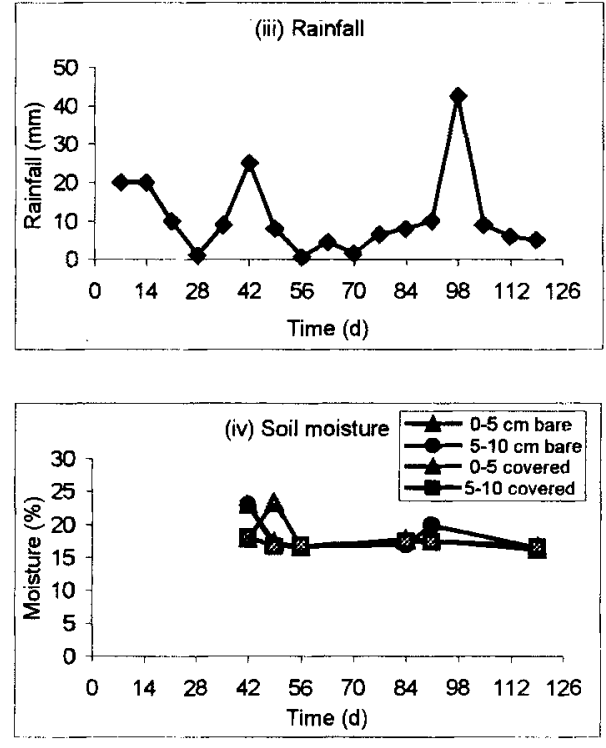

Fig. 1. Mean soil and environmental conditions recorded between microbial sampling events (Trial 1, 5 June - 28 August 2001 and Trial 2, 23 October 2001 - 19 Februany 2002)

During Trial 1 , the average temperature of bare soil was $20^{\circ} \mathrm{C}$. However, the plastic cover modified the soil environment, typically increasing soil temperatures by $4-5^{\circ} \mathrm{C}$ compared with bare soil. The plastic cover had a marginal warming effect in Trial 2 , increasing the soil temperature by $0.5^{\circ} \mathrm{C}$ relative to the bare ground. The minimum and maximum soil temperatures recorded in Trial 2 were $0.7^{\circ} \mathrm{C}$ and $13^{\circ} \mathrm{C}$, respectively. A series of soil wetting and drying cycles was observed during Trial
1, associated with significant rainfall events (e.g. $44.5 \mathrm{~mm}$ was recorded on Day 42) followed by dry periods and decreasing soil-moisture content (Fig. 1a). The plastic cover maintained the soil-moisture status at a higher value after rainfall compared with bare soil which dried rapidly during the spring/summer period. Small changes in soil moisture occurred in response to rainfall in the later trial but, in this case, the moisture content of the soil was maintained close to field capacity for the 
duration of the monitoring period in both covered and bare soil.

\section{Background Monitoring}

Four locations at the field station, representing different types of land-management practice, were sampled for $E$. coli on 17 July 2001, 6 November 2001 and 22 January 2002. The summer locations which were examined in July were two fallow sites, a rough grassland and woodland. The autumn locations included a footpath, a hedgerow, a fallow site and rough grassland area. The winter locations which were examined in January were a fallow site, rough grassland, woodland and a footpath.

\section{Sampling and Examination}

Biosolids were examined for $E$. coli before application to the experimental plots. Soil samples were collected immediately after application of the biosolids (Day 0), and the trials were monitored at weekly intervals for a period of 84 days for Trial 1 and 119 days for Trial 2. Soil amended with DMAD and the unamended control plots were re-sampled from both trials after 175 days to assess longer-term patterns in $E$. coli populations in soil. Samples were collected at two depths $(0-50 \mathrm{~mm}$ and $50-100$ $\mathrm{mm}$ ) using an auger which was sterilised in ethanol between each of the plots. Three soil cores were pooled from each experimental plot to provide a representative composite sample for microbiological examination.

The microbiological methods were adapted from UKWIR ${ }^{(0)}$, and samples of conventionally treated biosolids (DMAD) and soil receiving this type of sludge were examined by membrane filtration (MF). Enhanced treated biosolids and soils amended with these materials were enumerated using a 'most probable number' (MPN) technique.

Sample preparation involved aseptically transferring $10 \mathrm{~g}$ of soil or biosolids into $90 \mathrm{ml}$ of maximum recovery diluent (MRD) to achieve a 10fold dilution. The biosolids were homogenised by stomaching (Seward) for 2 mins in sterile stomacher bags. Soil samples were transferred to Duran bottles containing about $10 \mathrm{~g}$ of sterile glass beads, and were agitated on a shaker (Gerhardt) at $200 \mathrm{rev} / \mathrm{min}$ for 4 mins. Dilutions were prepared by transferring $1-\mathrm{ml}$ aliquots of the homogeneous solutions into $9 \mathrm{ml}$ of MRD to generate a log dilution series.

For the MF procedure, aliquots $(1 \mathrm{ml})$ of diluted solutions were filtered through $47 \mathrm{~mm}, 0.45 \mu \mathrm{m}$ gridded sterile membranes (Pall Gelman), and sterile deionised water was added to aid uniform dispersion over the surface of the membrane. The membrane was removed using sterile forceps and transferred to the surface of a dry 55-mm membrane lactose glucuronide agar (MLGA) plate, ensuring that no air bubbles were trapped between the membrane and the medium. The plates were inverted and incubated at $30^{\circ} \mathrm{C}$ for $4 \mathrm{~h}$, followed by $44^{\circ} \mathrm{C}$ for $14 \mathrm{~h}$. A further membrane was run in parallel on $\mathrm{m}-\mathrm{FC}$ agar plates ${ }^{(8)}$, and the plates were incubated at $44.5^{\circ} \mathrm{C}$ for $24 \mathrm{~h}$. Counts of $E$. coli were estimated by the enumeration of typical colonies and were reported as colony-forming units per $\mathrm{g}$ of fresh soil (cfu/g).

Increased sensitivity of detection was achieved using the MPN technique for soil and the enhanced treated sludge product where low numbers of $E$. coli were expected. Here, a $4 \times 5$ MPN matrix was prepared in lauryl tryptose broth containing bromocresol purple. The tubes were incubated at $36^{\circ} \mathrm{C}$ and examined for the presence of acid after $24 \mathrm{~h}$ and 48 $h$, indicated by a change in broth colour from purple to yellow. Tubes which produced a positive colour reaction were subjected to a confirmation procedure, and the remaining tubes were considered to be negative.

All positive MPN tubes were sub-cultured into $2 \%$ brilliant green bile broth (BGBB) containing an inverted Durham tube and tryptone water (TW). Both tubes were incubated at $44^{\circ} \mathrm{C}$ for $24 \mathrm{~h}$. The BGBB tubes were examined for turbidity and gas production in the Durham tube. Kovac's reagent was added to the TW tube to detect indole, and the development of a pink colouration indicated a positive reaction. The MPN was estimated from the number of tubes in the series which confirmed positive for $E$. coli using standard probability tables, and was reported per $100 \mathrm{~g}$ of fresh soil.

\section{RESULTS AND DISCUSSION}

Background populations of $E$. coli, which were detected in soil samples from different environmental locations, are presented in Table 1. More $E$. coli were recovered in soil at the autumn and winter sampling events when concentrations were in the range $1-5 \log E$. coli per $100 \mathrm{~g}$ of soil, compared with the summer season. Surface soil $(0-50 \mathrm{~mm})$ usually contained larger $E$. coli populations compared with the deeper soil layer $(50-100 \mathrm{~mm})$, suggesting that the deposition of faeces from wild animals and birds is likely to be a natural background source of $E$. coli.

Table 1. Background populations of $\mathrm{E}$. coli in soil samples at different depths and monitoring locations determined by 'most probable number' (MPN) technique

\begin{tabular}{l|c|c}
\hline Location and sampling date & $\begin{array}{c}\text { MPN/100 g }(\log 10) \\
0-50 \mathrm{~mm}\end{array}$ & $\begin{array}{c}\text { Fresh weight } \\
50-100 \mathrm{~mm}\end{array}$ \\
\hline 17 July 2001 & 2.23 & 1.11 \\
1. Fallow & 3.95 & 0.85 \\
2. Rough grassland & 0.30 & 0.30 \\
3. Fallow & $>4.20$ & $>4.20$ \\
4. Woodland & & \\
6 November 2001 & 4.95 & 3.95 \\
1. Footpath & 4.48 & 3.48 \\
2. Hedgerow & 3.70 & 3.23 \\
3. Fallow & $>5.20$ & 3.38 \\
4. Rough grassland & & \\
22 January 2002 & 4.70 & 1.30 \\
1. Woodland & 4.70 & 5.20 \\
2. Rough grassland & 4.11 & 3.38 \\
3. Fallow & 3.11 & $<1.30$ \\
4. Footpath & &
\end{tabular}

The importance of wildlife faeces as a source of enteric organisms in the environment was confirmed by the examination of $E$. coli in deer and rabbit droppings which were collected from the soil surface at the experimental site. Deer faeces contained $5.30 \log$ cfu/g DS of $E$. coli, and the concentration in rabbit droppings was $3.71 \mathrm{log}$ cfu/g DS. The field site was populated with a variety of wildlife, and these results emphasise that enteric micro-organisms, such as $E$. coli, from the faeces of wild birds and animals are a normal component of the natural background microbial flora in soil. This is also consistent with the observed presence and survival of faecal-indicator organisms from wild animals in agricultural and forestry soils treated with sewage sludge $e^{\{9,10\}}$.

\section{E. coli in Conventional and Enhanced Treated Biosolids}

The biosolids were tested prior to application in the field, and numbers of $E$. coli which are present in the different types of sludge are listed in Table 2. Digested sludge which was spread in Trial 1 contained $5.58 \mathrm{log} \mathrm{cfu} / \mathrm{g}$ DS of $E$. coli and was compliant with the US EPA's Class B status for pathogen reduction (less than $2 \times 10^{6}$ faecal coliforms per $\mathrm{g}$ $D S)^{11}$, but marginally exceeded the proposed UK numerical standard for conventionally treated biosolids (less than $10^{5} E$. coli per g DS ${ }^{(3)}$ ). 
However, the DMAD which was applied to Trial 2 contained $7.08 \mathrm{log} \mathrm{cfu} / \mathrm{g}$ DS of $E$. coli, exceeding the numerical microbiological quality limits for agricultural use of this type of sludge product. As would be expected, the enhanced-treated materials contained fewer $E$. coli than DMAD. For example, the composted sludge contained $3.72 \mathrm{log} / 100 \mathrm{~g}$ DS of $E$. coli, and there were less than $1.30 \mathrm{log} / 100 \mathrm{~g}$ DS of the faecal-indicator bacteria in TDD. Both products met the US EPA Class A requirements for unrestricted use ${ }^{(1)}$ ) and the proposed UK standard for enhanced treatment (less than $10^{3} E$. coli per $\mathrm{g} \mathrm{DS}^{(3)}$ ). The TDD would also comply with the more stringent microbiological criteria proposed by the European Commission for enhanced-treated products (less than $5 \times 10^{2}$ E. coll per g DS) ${ }^{(12)}$.
Table 2. E. coli (log10 cfu/g) in biosolids applied to field experiments

\begin{tabular}{l|l|l|l|l|l}
\hline Sludge type and trial & $\begin{array}{l}\text { DS } \\
(\%)\end{array}$ & cfu/g FW & cfu/g DS & $\begin{array}{l}\text { MPN } \\
(100 / g \\
\text { FW })\end{array}$ & $\begin{array}{l}\text { MPN } \\
(100 / g \\
\text { DS) }\end{array}$ \\
\hline Trial 1 & & & & & \\
Dewatered digested (DMAD) & 29.7 & 5.05 & 5.58 & & \\
Compost (CPT) & 57.6 & & & 3.48 & 3.72 \\
Thermally dried digested (TDD) & 99.5 & & & $<1.30$ & $<1.30$ \\
\hline Trial 2 & & & & & \\
Dewatered digested (DMAD) & 22.9 & 6.44 & 7.08 & & \\
Compost (CPT) & 62.8 & & & $<0.30$ & $<0.50$ \\
Thermally dried digested (TDD) & 92.8 & & & $<0.30$ & $<0.33$ \\
\hline
\end{tabular}

$\mathrm{FW}=$ Fresh weight

DS = Dry solids (a) Trial 1
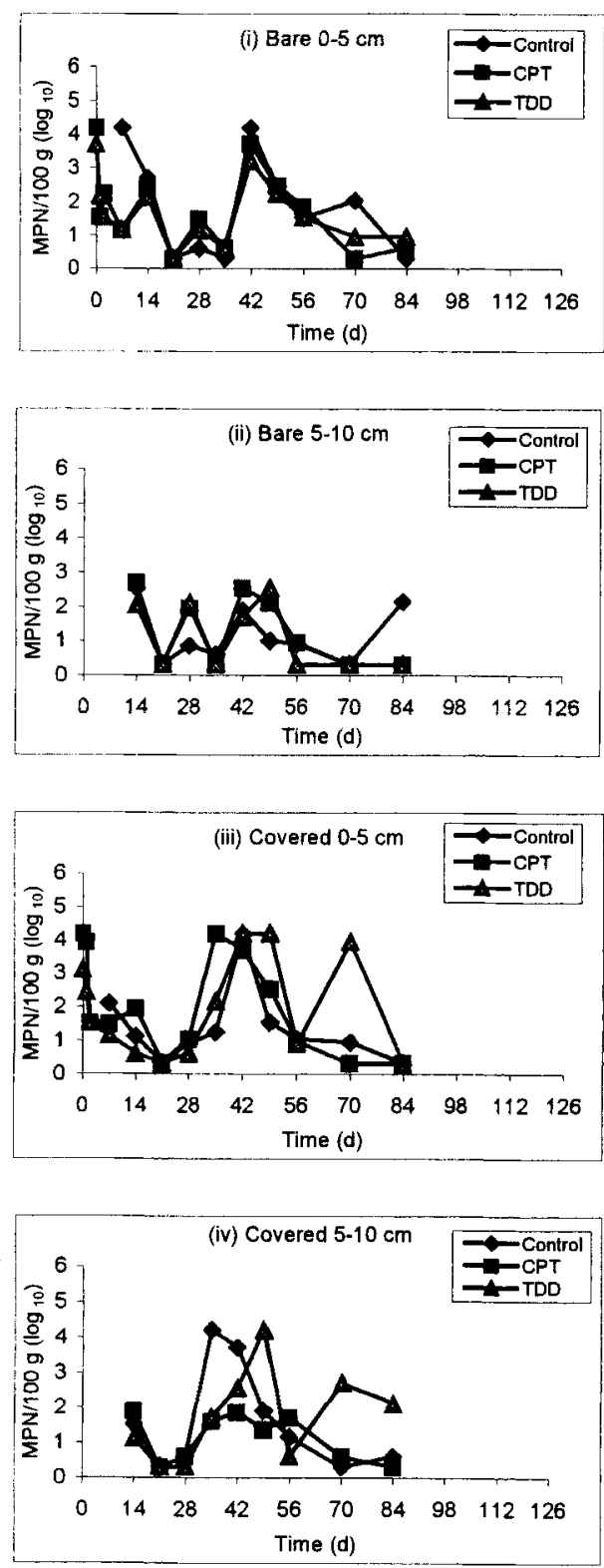

(b) Trial 2
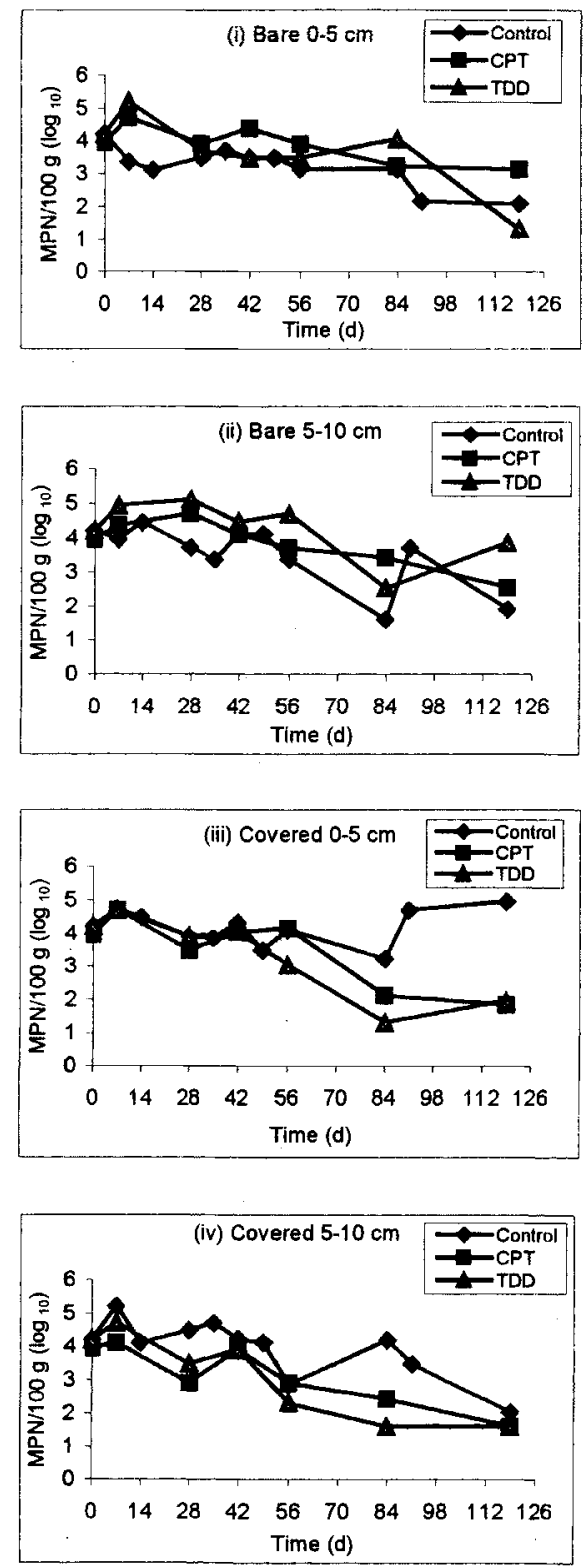

Fig. 2. E. coli populations in soil amended with enhanced treated biosolids and in untreated soil at two depths, with and without a perforated plastic soil cover (Trial 1, 5 June - 28 August 2001 and Trial 2, 23 October 2001 - 19 February 2002) 


\section{E. coli Decay in Soil Enhanced treated biosolids}

The numbers of $E$. coli in soil receiving enhanced-treated products were similar to the background populations in unamended control soils in both trials (Fig. 2). Indeed, on the day of application in Trial 2 (Fig. 2b), there was no discernible difference in counts between the treated and control soils. These recoveries of faecal organisms were also comparable with the indigenous microbial populations which are normally present in soil associated with general inputs of enteric bacteria from environmental sources (Table 1).

The decline and re-population of indigenous $E$. coli were observed in Trial 1 in both covered and bare soil supplied with enhanced-treated biosolids and in the unamended soil control (Fig. 2a). Small recoveries of E. coli from soil (less than $0.30 \mathrm{log} / 100 \mathrm{~g}$ ) detected by the MPN method coincided with periods of low soil-moisture status (Fig. 1a). However, populations rapidly re-established up to $2-4 \log / 100 \mathrm{~g}$ at Day 14,28 and 42 upon soil rewetting following relatively high mean rainfall events (Fig. 1a). In contrast, E. coli populations in Trial 2 showed a more consistent pattern of behaviour during the autumn and winter monitoring periods (Fig. 2b) when the soil moisture remained close to field capacity (Fig. 1b). In this case, there was evidence of a general decline in the soil population from initial values of about $4 \log / 100 \mathrm{~g}$ to $2-3 \log / 100 \mathrm{~g}$ during the December-February period. Populations of $E$. colli in cultivated soil were generally similar at both monitoring depths in Trial 1 and Trial 2 , suggesting that the bacteria were indigenous to the soil and were not predominantly associated with inputs from the faeces of wild animals, although this was also identified as a potential source of $E$. colientering the soil. The plastic cover influenced the soil environment, particularly during the spring season for Trial 1, by generally increasing the soilmoisture content and temperature compared with the bare soil. This provided a more favourable environment for bacterial activity and extended the period of soil re-population with $E$. coli relative to soil samples from the drier bare plots. Enhanced treated biosolids did not supply significant numbers of $E$. coli to the soil. However, the sludge products apparently modified the soil habitat and increased the longevity of bacterial re-population in covered soil, although this was not evident in the bare ground phots. Soil moisture was relatively consistent in both covered and bare soil following the autumn application of sludge to Trial 2 and, whilst there was a small elevation in soil temperature under the cover (Fig. 1b), there was little difference apparent in $E$. coli populations between these soils.

The numbers of enteric bacteria in the soil might increase in response to soil wetting, particularly following a period of dry soil conditions, and this has been attributed to regrowth of the bacterial population ${ }^{(13.14)}$. However, the rapid changes in the background numbers of $E$. coli when soil moisture increased following significant rainfall after periods of $d y$ weather suggests that an alternative survival mechanism might be operating in the indigenous flora. It is well known that soil bacteria can readily adapt to changing environmental and edaphic conditions ${ }^{(15.6)}$. The population dynamics in Trial 1 suggest that indigenous $E$. coli might adapt to the soil environment by entering a viable, but non-culturable, latent state when the soil is $d r y$. The bacteria return to a culturable condition when the soil-moisture content is increased, apparently rapidly re-populating the soil. The soil-moisture content remained close to field capacity during Trial 2 in the autumn/winter period and, in this case, the background numbers of $E$. coli in the soil were generally more consistent than those observed in the earlier spring/summer season.

\section{Conventionally treated biosolids}

$E$. coli were enumerated in soil amended with DMAD using two chromogenic agars (MLGA and $\mathrm{m}-\mathrm{FC}$ ), and the numbers of enteric bacteria isolated from sludged soil were similar with both methods (Fig. 3). As expected, the application of sludge increased the numbers of $E$. coli in soil, and the initial population size (Day 0) was 4-5 log cfu/g, which was consistent with the rate of addition in sludge, the incorporation depth and the associated dilution in soil after uniform sludge incorporation. However, E. coli in soil receiving the conventionally treated product declined by $99.0-99.9 \%(2-3 \log )$ within a 56 -day period and decreased to background values, which was comparable with the unamended control within 91 days after application - irrespective of the marked differences in environmental conditions occurring during the spring/summer and autumn/winter seasons (Fig. 1). The trials were resampled 175 days after sludge incorporation, and the numbers of $E$. coli were less than $1 \mathrm{log}$ cfu/g in both the control and sludge-amended plots.
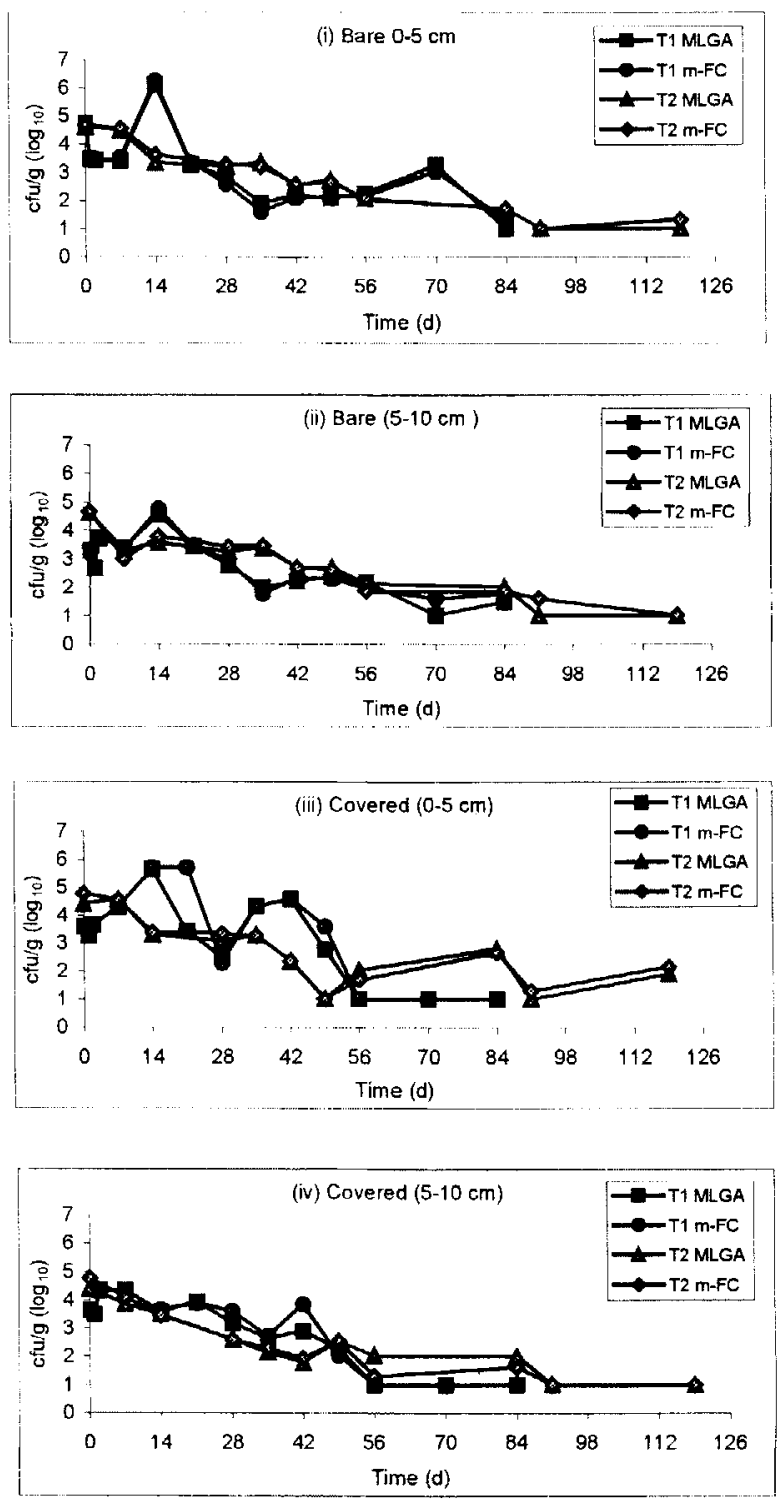

Fig. 3. E. coli, enumerated with MLGA or $m-F C$, in soil amended with dewatered mesophilic anaerobically digested biosolids (DMAD) at two soil depths, with and without a perforated plastic soil cover (T1 = Trial 1, 5 June -28 August 2001 and $T 2=$ Trial 2, 23 October $2001-19$ February 2002) 
These results demonstrate that $E$. coli in arable soil which has been amended with conventionally treated biosolids decline to background values within 2-3 months of applying sludge in the field irrespective of environmental conditions. This is consistent with early reports ${ }^{(17)}$ of survival periods of 2-3 months for enteric pathogens in sludge-treated temperate soils. The data also provide assurance that (a) residual numbers of pathogens applied to soil in treated biosolids decay to background values well within the cropping and harvesting restrictions which are stipulated for agricultural use ${ }^{(1,2)}$, and (b) the waiting periods which are specified in the controls are likely to provide a significant margin of safety.

\section{CONCLUSIONS}

1. Enhanced treated biosolids do not contribute $E$. coli to the indigenous soil population. However, soil-organic amendments can extend the longevity and survival of indigenous $E$. coli after rewetting dry soil by modifying soil conditions.

2. Enhanced treatment provides a critical control point for the potential microbiological risk associated with the application of biosolids to soil. Technically, restrictions on the uses of sludge products achieving this microbiological standard are an unnecessary precaution and could limit valid opportunities for recycling these materials on land.

3. The application of conventionally treated biosolids will increase $E$. coli above ambient values in soll; however, survival is limited to 2-3 months - irrespective of environmental conditions or the timing of applications in the field.

4. The decay of $E$. coli to negligible numbers in arable soil receiving conventionally treated biosolids occurs well within the cropping/harvesting restrictions which are prescribed in legislation and guidance controlling the application of sewage sludge on farmland.

5. The data are encouraging and indicate that microbiological risks from the agricultural use of sewage sludge are managed effectively by either (a) treating sludge to enhanced status to eliminate enteric organisms, or (b) treating sludge by conventional methods to significantly reduce its pathogen content. Also, by adopting precautionary cropping and harvesting restrictions to permit natural decay of microbial pathogens, a dual barrier is introduced.

6. Further work is necessary to support the use of sludge in agriculture by assessing the decay of enteric organisms in different types of soil and also to extend the research to consider a range of other pathogens.

\section{ACKNOWLEDGEMENTS}

The project forms part of a programme of research (Predicting Agricultural Benefit of Novel Biosolids Products) which is being funded by the Environment Agency, Severn Trent Water, Thames Water, Yorkshire Water, the Scottish Water Authorities and the EPSRC.

\section{REFERENCES}

(1) AGRICULTURAL DEVELOPMENT AND ADVISORY SERVICE. The Safe Sludge Matrix. (3rd Edition.) Guidelines for the application of sewage sludge to agricultural land. ADAS, Mansfield, 2001.

(2) DEPARTMENT OF THE ENVIRONMENT. Code of Practice for Agricultural Use of Sewage Sludge. HMSO, London, 1996.

(3) SWEET, N., MCDONNELL, E., COCHRANE, J. AND PROSSER, P. The new Sludge (Use in Agriculture) Regulations. In Proc.of CIWEM/AquaEnviro 6th European Biosolids and Organic Residuals Conf., Wakefield, 11-14 November, 2001.

(4) ROYAL COMMISSION ON ENVIRONMENTAL POLLUTION. Nineteenth Report: Sustainable Use of Soil. Cmd 3165. HMSO, London, 1996.

(5) EVANS, S. R. A case control study of multiple resistant Salmonella typhimurium DT 104 infection of cattle in Great Britain. Cattle Practice, 1996, 4, 259.

(6) COUNCIL OF THE EUROPEAN COMMUNITIES. Council Directive of 12 June 1986 on the protection of the environment, and in particular of the soil, when sewage sludge is used in agriculture (86/278/EEC). Official Journal of the European Communities, №. L181/6-12, 1986.

(7) UK WATER INDUSTRY RESEARCH. A Survey of $E$. coli in UK Sludges (99/SU/06/3). UKWIR, London, 1999.

(8) AMERICAN PUBLIC HEALTH ASSOCIATION. Standard Methods for the Examination of Water and Wastewater. (20th edition.) United Book Press, Maryland, USA, 1998.

(9) EDMONDS, R. L. AND MAYER, K. P. Survival of coliform bacteria in sewage sludge applied to a forest clearcut and potential movement into groundwater. App. Envir. Microbiol., 1976, 32, 537.

(10) WALLIS, P. M., LEHMANN, D. L., MACMILLAN, D. A. AND BUCHANANMAPPIN, J. M. Sludge application to land compared with a pasture and a hayfield: reduction of biological health hazard over time. J. Envir. Qual., 1984, 13, 645.

(11) US ENVIRONMENTAL PROTECTION AGENCY. Part 503. Standards for the use or disposal of sewage sludge. Federal Register, 1993, 58, 9387.

(12) EUROPEAN COMMISSION. Working document on sludge; 3rd draft ENV.E.3/LM, DG Environment, Brussels, 2000.

(13) GIBBS, R. A., HU, C. J., HO, G. E. AND UNKOVICH, I. Re-growth of faecal coliforms and salmonellae in stored biosolids and soil amended with biosolids. Wat. Sci. Technol., 1997, 35, 269.

(14) YANKO, W. A., GLASS, J. S., VAN SLUIS, R. J., DAHLEGREN, J. A. AND EASLY, R. C. Survival of pathogenic and indicator micro-organisms in sewage sludge amended agricultural soil winter and summer growing seasons, 1977. Country Sanitation Districts of Los Angeles County, San Jose Creek Water Quality Lab, Whittier California, USA, 1978.

(15) ATLAS, R. M. AND BARTHA, R. Microbial Ecology Fundamentals and Application. (3rd edition.) Benjamin/Cummings Publishing Company, California, USA, 1993.

(16) ADAMS, M. R. AND MOSS, M. O. Food Microbiology. (2 $2^{\text {id }}$ edition.) Royal Society of Chemistry, Cambridge, 2000.

(17) ENGELBRECHT, R. S. Microbial hazards associated with the land application of wastewater and sludge. Pub. Hith Eng., 1974, 6, 219. 